\title{
Water Resource Optimization, a Path Toward Sustainable Development
}

\author{
Shiva Ourang ${ }^{1 *}$ and Shah Md Imran Kabir ${ }^{2}$ \\ ${ }^{1}$ School of Civil Engineering, College of Engineering, University of Tehran, Iran \\ ${ }^{2}$ Department of Civil Engineering, College of Engineering, University of Texas at Arlington, USA
}

Submission: December 4, 2017; Published: January 19, 2017

*Corresponding author: Shiva Ourang, School of Civil Engineering, College of Engineering, University of Tehran, Iran, Email: sh.ourang@ut.ac.ir

\begin{abstract}
Currently, water is very valuable, so should be used optimally. Planning for optimal use of water and soil resources will protect these resources and bring about increased production, growth in farm income, and enhancement of rural economic prosperity. This study was performed with the aim of improving management of water resources on Pakdasht Plain lands using a combination of typical and linear goal optimization techniques that in this study are used to examine optimal allocation of water and prioritization of cultivation patternswith respect to water consumption. In this study, the effects of limits on irrigation on the products of system cultivation patterns have also been evaluated.

Keywords: Conjunctive harvesting; Water productivity; Optimization; Pakdasht irrigation system; Goal programming
\end{abstract}

\section{Introduction}

Because Iran is located in a warm and dry region, most plains of Iran require proper management of water resources and optimization of water consumption to maximize exploitation of limited water resources [1,2]. A sustainable water management policy for agricultural irrigation is to promote water use in such a way that society's needs are met to the greatest extent possible, both now and in the future. Linear Programming (LP) and principal components analysis have long been used to select descriptive variables for relating runoff to climate and watershed descriptors $[3,4]$. Statistical prediction methods, on the other hand, rely on past historical data for prediction [5-10]. LP approaches have always been used to obtain optimal strategies, such as water-allocation patterns, crop-planting plans, and canal-expansion schemes, with the objective of maximizing net benefit [11]. One of the main solutions in the agriculture sector, the largest consumer of water resources, is conjunctive use of surface and ground water resources. Launching a suitable and optimal cultivation pattern undoubtedly can have a significant effect on reducing water consumption and elevating profits in an agriculture system [12-16]. The main aim of this study is development and application of a model for managing surface and ground water resources and achieving an optimal cultivation pattern.

\section{Case Study}

The Pakdasht Plain is located in the northern part of Iran in the southern ranges of Alborz, $40 \mathrm{~km}$ southeast of Tehran, between $33^{\circ}$ and $51^{\circ}$ up to $40^{\circ}$ and $41^{\circ}$ of eastern longitude, and $5^{\circ}$ and $35^{\circ}$ up to $30^{\circ}$ and $35^{\circ}$ of the northern latitude [17] (Figure 1).

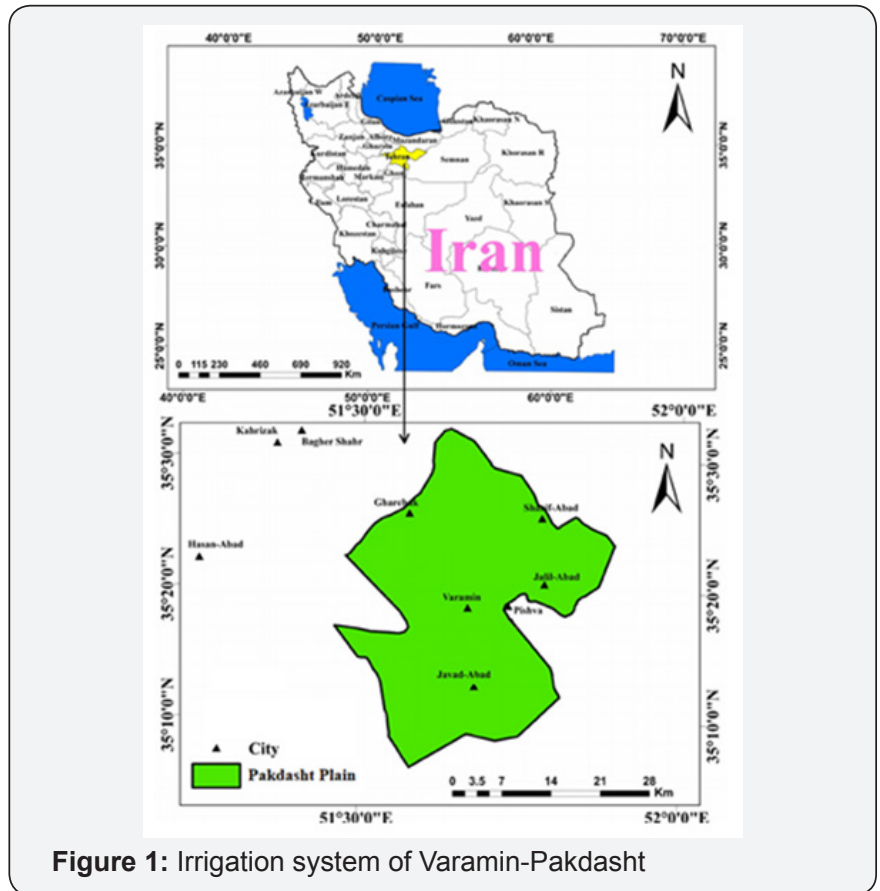

\section{Methods and Materials}

This study used the optimization approach that was developed and used by Daghighi et al. [14] on Arjan plain, 
Fars province. The approach used in the mentioned studywas a reliable, effective, and possible solution for the Arjan plain water resource issuesand wascalibrated based on the specified local farmer's goal and the tangible existing constraints. Based on discussion with local authorities and agriculture producers in the Arjan plain, the authors found out that after implementing new water resource policies, obtained from the result of the mentioned study, the revenue have been twenty percent increased.

The general structure of a fractional multi-objective goal programming model used in the studycan be formulated as shown in Equation 1.

$$
\left\{\frac{\sum_{i} N_{i} X_{i}}{\sum_{i} W_{i} X_{i}}, \frac{-\sum_{i} G W_{i} X_{i}}{\sum_{i} W_{i} X_{i}}\right\} \text { Equation } 1
$$

Where, $\mathrm{i}$ is number of products $(\mathrm{i}=1,2, \ldots), \mathrm{Ni}$ is the net profit of the ith product except for water cost, $\mathrm{X}_{\mathrm{i}}$ is the area under cultivation for the ith product in the region (in hectares), $\mathrm{W}_{\mathrm{i}}$ is the total water consumed for the $\mathrm{i}^{\text {th }}$ product in the cultivation season $\left(102 \mathrm{~m}^{3} / \mathrm{ha}\right), \mathrm{GW}_{\mathrm{i}}$ is the groundwater used in the region for the ith product $\left(10^{2} \mathrm{~m}^{3} / \mathrm{ha}\right), \frac{\Sigma_{N} N_{X} X_{X}}{\Sigma W_{X}}$ is the total profit for the total water consumed (productivity), and $\frac{-\Sigma_{i} G W_{i} X_{i}}{\Sigma_{i} W_{i} X_{i}}$ is the ratio of total groundwater to the total water consumed.

The model is linear programming (LP) for profit maximization. This model has been developed considering different values of reduction or increase of withdrawal from groundwater [18]. For all of the above-mentioned options, the LP model was written and the values of areas of cultivation and consumed water were compared.

\section{Results and Discussion}

In this study, 22 options were studied.The first wasto use the typical cultivation patterns of the region with respect to wheat, barley, alfalfa, cotton, and cucurbits (tomato, eggplant, and pumpkin). The current total area under cultivation in the region is 52,455 hectares, and the maximum area under cultivation is currently allocated to barley, then to wheat, with respective values of 13,500 and 13,075 hectares.

For the second to tenth options, different amounts of groundwater reduction were applied, and the profit and areas under cultivation were compared with one another. These options were chosen to preserve or improve the situation with respect to groundwater aquifers. In these options, reductionsranging from $60 \%$ to $0 \%$ were considered. The total groundwater volume for this purpose varied between 179.44 and 448.61 million $\mathrm{m}^{3}$ per year for the second to tenth options.

In the eleventh to sixteenth options, increase of withdrawal from groundwater was considered to examine the resulting trend of changes with respect to profit and areas under cultivation. This increased withdrawal was incremented by up to $25 \%$ i.e., up to 560.76 million $\mathrm{m}^{3} /$ year. For these options, increased groundwater withdrawal causes excessive pressure on groundwater aquifers.

The $16^{\text {th }}$ to $22^{\text {nd }}$ options have been allocated different reduced irrigation levels. Implementing reduced irrigation by up to $40 \%$ and calculating the performance value resulted in the area under cultivation growing by up to 74165 hectares, a $41 \%$ increase in the area under cultivation Table 1.

For all options, the entire volume of available surface water in the plain (141.92 billion $\mathrm{m}^{3} /$ year) was used. The maximum profit was associated with Option 15, representing $25 \%$ more groundwater withdrawal, about 560.76 million $\mathrm{m}^{3} /$ year, in relation to current conditions. In this option, the profit is 1.52 times as large as that for the current state (2162 billion Rials). Implementation of this option is only possible if the groundwater aquifers could be fed by resources other than the internal resources of the plain, otherwise we would observe a dramatic decrease in the water table level of Pakdasht Plain.

Minimum profit occurs for Option 2, where groundwater withdrawal decreases by $60 \%$ (179.4 million $\mathrm{m}^{3} /$ year) in comparison to the current state.For this case, the profit reaches 0.57 of the current value (816.4 billion Rials). Implementation of this option, representinga descending trend in water table level of the region in the upcoming years, would be likely to ultimately result in devastation of the plain. For other options with elevated groundwater withdrawal (Options 2 to 15), the profit grows. This increase grows faster in Options 2 to 6 than in options 7-15. In other options (16 to 22), if low irrigation is implemented, although the area under cultivation grows, the profit diminishes significantly. The results obtained from the linear model of profit maximization and areas under cultivation are shown in Figure 2.

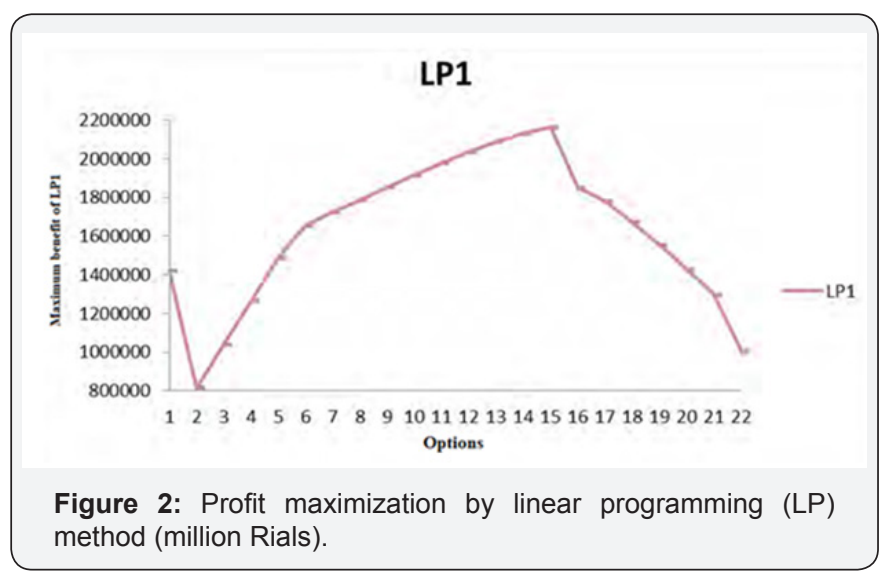

As shown in Table 1, with decreased groundwater withdrawal and without applying reduced irrigation, the area under cultivation in the plain decreased, and in the minimum state it reached 28,635 hectares in 0ption 2. As expected, in this state the areas under cultivation approach the lower limit set for them, and the area under cultivation of the crops decreased significantly with huge water consumption. By applying reduced irrigation and associated water stress by up to $40 \%$, 
the total area under cultivation reached 88,408 hectares (Option 22). If this option and other options are investigated, the deficit of irrigation water for the mentioned plain becomes more evident. Implementation of option (22), considering its low water productivity (0.17), would only be recommended for reasons other than profit, perhaps for cultivating a large area of the plain to improve employment conditions.

Table 1: Introduction of the studied options and their areas under cultivation.

\begin{tabular}{|c|c|c|c|c|}
\hline Options & $\mu$ & Dehydration Rate & $\begin{array}{l}\text { Total Cultivated Area } \\
\text { Under Ideal Condition }\end{array}$ & $\begin{array}{l}\text { Total Cultivated Area } \\
\text { Under Deficit Conditions }\end{array}$ \\
\hline 1 & - & - & - & - \\
\hline 2 & 0.4 & 0 & - & - \\
\hline 3 & 0.5 & 0 & - & - \\
\hline 4 & 0.6 & 0 & - & - \\
\hline 5 & 0.7 & 0 & - & - \\
\hline 6 & 0.8 & 0 & 40699 & 40904 \\
\hline 7 & 0.85 & 0 & 40699 & 40904 \\
\hline 8 & 0.9 & 0 & 40699 & 40904 \\
\hline 9 & 0.95 & 0 & 40699 & 40904 \\
\hline 10 & 1 & 0 & 40699 & 40904 \\
\hline 11 & 1.05 & 0 & 40699 & 40904 \\
\hline 12 & 1.1 & 0 & 40699 & 40904 \\
\hline 13 & 1.15 & 0 & 40699 & 40904 \\
\hline 14 & 1.2 & 0 & 40699 & 40904 \\
\hline 15 & 1.25 & 0 & 40699 & 40904 \\
\hline 16 & 1 & 0 & 47578 & 41463 \\
\hline 17 & 1 & 10 & 50437 & 41700 \\
\hline 18 & 1 & 15 & 52927 & 41700 \\
\hline 19 & 1 & 20 & 56655 & 41700 \\
\hline 20 & 1 & 25 & 59394 & 41700 \\
\hline 21 & 1 & 30 & 61163 & 41700 \\
\hline 22 & 1 & 40 & 74165 & 41700 \\
\hline
\end{tabular}

\section{Conclusion}

In this study, the effect of application of reduced irrigation on crops in the system's cultivation patternwas examined, with results indicating that,for implementing Options 16 and 17 , corresponding to 5 and $10 \%$ reduced irrigation, the extent of groundwater allocation decreases from 448.61 to 338.108 and 317.634 million $\mathrm{m}^{3} /$ year, respectively, representing 26.63 and $29.2 \%$ decrease in withdrawal.

These research findings suggest that the planning axis (profit and water productivity or stability in use of groundwater resources) plays a key role in the process of management and allocation of water resources of the system, and under abnormal conditionsand crises resulting from drought or climate change, a different approach would be demanded.

\section{References}

1. Nahvi A, Daghighi A, Nazif S (2017) The Environmental Impact Assessment of Drainage Systems: A Case Study of the Karun River Sugarcane Development Project. Archives of Agronomy and Soil Science, (just-accepted) 64(2): 185-195.
2. Akram M, Azari A, Nahvi A, Bakhtiari Z, Safaee HD (2013) Subsurface drainage in Khuzestan, Iran: environmentally revisited criteria. Irrigation and Drainage 62(3): 306-314.

3. Llamas MR, Custodio E (2003) Intensive use of groundwater: a new situation which demands proactive action. Intensive use of groundwater: Challenges and opportunities p. 13-31.

4. Lu HW, Huang GH, Zeng GM, Maqsood I, He L (2008) An inexact two-stage fuzzy-stochastic programming model for water resources management. Water Resources Management 22(8): 991-1016.

5. Castelletti A, Pianosi F, Soncini-Sessa R (2008) Integration, participation and optimal control in water resources planning and management. Applied Mathematics and Computation 206(1): 21-33.

6. Lu H, Huang G, He L (2011) An inexact rough-interval fuzzy linear programming method for generating conjunctive water-allocation strategies to agricultural irrigation systems. Applied Mathematical Modelling 35(9): 4330-4340.

7. Anwar AA, Clarke D (2001) Irrigation scheduling using mixed-integer linear programming. Journal of Irrigation and Drainage Engineering 127(2): 63-69.

8. Barthold VV (2014) An historical geography of Iran. Princeton University Press.

9. Battude M, Al Bitar A, Brut A, Tallec T, Huc M, et al. (2017) Modeling water needs and total irrigation depths of maize crop in the south 
west of France using high spatial and temporal resolution satellite imagery. Agricultural Water Management 189: 123-136.

10. Bussieck MR, Meeraus A (2004) General algebraic modeling system (GAMS). Applied Optimization 88: 137-158.

11. Daghighi A (2017) Harmful Algae Bloom Prediction Model for Western Lake Erie Using Stepwise Multiple Regression and Genetic Programming (Doctoral dissertation, Cleveland State University), (last access: 15 January 2018).

12. Daghighi A, Nahvi A, Kim U (2017) Optimal Cultivation Pattern to Increase Revenue and Reduce Water Use: Application of Linear Programming to Arjan Plain in Fars Province. Agriculture 7(9): 73.

13. Habibzadeh Bigdarvish 0 (2017) On the modeling of thermo-active diaphragm walls by numerical analyses and monitoring data.

14. He L, Huang GH, Zeng GM, Lu HW (2008) Wavelet-based multi resolution analysis for data cleaning and its application to water quality management systems. Expert Systems with Applications 35(3): 1301-1310.

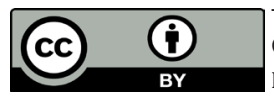

This work is licensed under Creative Commons Attribution 4.0 License

DOI: $10.19080 / \mathrm{NFSIJ} .2018 .04 .555645$
15. Karandish F, Šimůnek J (2017) Two-dimensional modeling of nitrogen and water dynamics for various N-managed water-saving irrigation strategies using HYDRUS. Agricultural Water Management 193: 174190.

16. Lawston PM, Santanello JA, Franz TE, Rodell M (2017) Assessment of irrigation physics in a land surface modeling framework using nontraditional and human-practice datasets. Hydrol Earth Syst Sci 21(6): 2953-2966.

17. Leng G, Leung LR, Huang M (2017) Significant impacts of irrigation water sources and methods on modeling irrigation effects in the ACME Land Model. Journal of Advances in Modeling Earth Systems 9(3): 1665-1668.

18. Lu HW, Huang GH, Lin YP, He L (2009) A two-step infinite $\alpha$-cuts fuzzy linear programming method in determination of optimal allocation strategies in agricultural irrigation systems. Water resources management 23(11): 2249-2269.

\section{Your next submission with Juniper Publishers will reach you the below assets}

- Quality Editorial service

- Swift Peer Review

- Reprints availability

- E-prints Service

- Manuscript Podcast for convenient understanding

- Global attainment for your research

- Manuscript accessibility in different formats ( Pdf, E-pub, Full Text, Audio)

- Unceasing customer service

Track the below URL for one-step submission https://juniperpublishers.com/online-submission.php 